\title{
KEPEMIMPINAN NON-MUSLIM: PENAFSIRAN SURAT AL-MAIDAH AYAT 51 DALAM TAFSIR AL-AZHAR DAN TAFSIR AL-MISHBAH
}

\author{
Muhammad Wahyudi \\ UIN Sunan Kalijaga Yogyakarta, Indonesia \\ E-mail: yudiana026@gmail.com
}

\begin{abstract}
Abstrak
Artikel ini ingin menjelaskan penafsiran Surat Al-Maidah Ayat 51 dalam dua kitab tafsir, yaitu Tafsir Al-Azhar yang ditulis oleh Haji Abdul Karim Malik Amrullah (Hamka) dan Tafsir Al-Mishbah karya M. Quraish Syihab. Naskah ini ingin membandingkan perspektif dalam penafsiran keduanya terhadap Surat Al-Maidah Ayat 51 mengenai kepemimpinan non-Muslim. Model penafsiran keduanya patut dikaji dan relevan karena sama-sama menuliskan kitab tafisrnya berdasarkan metode tahlili (analitis), yaitu menafsirkan ayat-ayat Al-Qur'an dengan memaparkan berbagai aspek yang terkandung di dalam ayat-ayat yang sedang ditafsirkan itu serta menerangkan makna-makna yang tercakup di dalamnya. Selain itu, dua kitab tafsir ini memiliki kesamaan corak penafsiran adabi ijtima'i, sebuah corak yang menggambarkan serta menguraikan penafsirannya berbasis fakta sosial. Artikel ini menyimpulkan bahwa Hamka menafsirkan surat Al-Maidah ayat 51 sebagai larangan mutlak untuk menjadikan nonMuslim sebagai pemimpin di kalangan muslim. Ia berargumen, non-muslim akan selalu berusaha berbuat buruk kepada Muslim. Sedangkan M. Quraish Shihab menafsirkan ayat ini tidak sebagai larangan mutlak. Non-Muslim yang hidup damai dengan masyarakat Muslim memiliki hak dan kewajiban yang sama dengan Muslim, begitu juga dalam hak untuk menjadi pemimpin.
\end{abstract}

Kata Kunci: Al-Maidah Ayat 51, Hamka, Kepemimpinan Non-Muslim, Tafsir Al-Mishbah, Tafsir Al-Azhar, Quraish Syihab

\begin{abstract}
This article wants to explain the interpretation of Surah Al-Maidah Verse 51 in two interpretive books, namely Tafsir Al-Azhar written by Haji Abdul Karim Malik Amrullah (Hamka) and Tafsir AlMishbah by M. Quraish Syihab. This text wants to compare the perspectives in the interpretation of the two of Surat Al-Maidah Verse 51 regarding non-Muslim leadership. Both models of interpretation deserve to be studied and relevant because both write their tafisr books based on the tahlili (analytical) method, which is to interpret the verses of the Koran by describing various aspects contained in the verses being interpreted and explaining the meanings. the meaning it entails. In addition, these two tafsir books have the same style of interpretation as adabi ijtima'i, a style that describes and describes the interpretation based on social facts. This article concludes that Hamka interprets Surah Al-Maidah verse 51 as an absolute prohibition against making non-Muslims as leaders among Muslims. He argued
\end{abstract}


that non-Muslims would always try to do bad things to Muslims. Meanwhile, M. Quraish Shihab interprets this verse not as an absolute prohibition. Non-Muslims who live in peace with Muslim communities have the same rights and obligations as Muslims, as well as the right to become leaders.

Keyword: Al-Maidah Verse 51, Hamka, Non-Muslim Leadership, Tafsir Al-Mishbah, Tafsir Al-Azhar, Quraish Syihab

\section{Pendahuluan}

Di antara persoalan hukum Islam (fikih) yang selalu hangat untuk diperbincangkan adalah persoalan kepemimpinan. Ini dipengaruhi oleh banyak sebab. Di antaranya, sebagaimana umumnya tema-tema lain dalam fikih, tema kepemimpinan dirujukkan pada landasan AlQur'an dan al-Sunnah. Semntara di sisi lain, pembacaan terhadap kedua sumber hukum Islam dimungkinkan untuk terjadinya keragaman pemahaman dan tafsir. Kedua, kerancuan berpikir di kalangan umat sehingga sulit memilah antara sumber hukum Islam yang sakral dengan turunan dari kedua sumber hukum tersebut sebagai buah pikiran manusia yang sesungguhnya dapat dikritisi (qabil li al-niqash). ${ }^{1}$

Dewasa ini, hangat diperbincangkan mengenai kepemimpinan non-Muslim di tengah masyarakat muslim. Pada tanggal 15 Februari 2017 kemarin, Indonesia telah melaksanakan pilkada (pemilihan kepada daerah) serentak. Dalam pilkada tersebut siapa saja yang memiliki syarat-syarat tertentu berhak mencalonkan dirinya menjadi pemimpin, baik itu seseorang dari kalangan Muslim maupun non-Muslim, dari kalangan politik atau pengusaha. Kaitannya dengan pilkada serentak tersebut, DKI Jakarta tampil sebagai daerah yang kontroversial. Pasalnya terdapat non-Muslim, yaitu Basuki Tjahya Purnama (Ahok) yang mencalonkan dirinya sebagai pemimpin. ${ }^{2}$

Kontroversi bahkan hingga penolakan terhadap kepemimpinan Ahok, sebenarnya sudah muncul ketika ia menggantikan Joko Widodo, yang terpilih sebagai Presiden Republik Indonesia pada tahun 2014. Bentuk penolakan tersebut mulai dari bisik-bisik lirih orang per orang sampai penolakan yang bersifat terbuka. Tidak saja Fron Pembela Islam (FPI) yang menunjukan sikap antagonis sejak Ahok menjadi wakil Gurbernur tetapi juga kelompok Islam arus utama seperti perwakilan Nahdatul Ulama Jakarta Selatan, Ketua Habib Muda Jakarta, Ketua Forum Betawi Bersatu, serta Sekretaris Jendral MUI. ${ }^{3}$

\footnotetext{
${ }^{1}$ Wawan Gunawan Abdul Wahid, Fikih Kepemimpinan Non-Muslim, dalam Fikih Kebinekaan (Ma'arif Institute dan Mizan : Bandung), 317.

2 Lulu Nadziroh,Pemimpin non-Muslim menurut Ibnu Taimiyah dan Relevansinya dengan Kontroversi Pilkada di DKI Jakarta Tahun 2017, Skripsi Fakultas Ushuluddin dan Pemikiran Islam UIN Sunan Kalijaga 2017, hlm 2.

3 Siti Ruhaini Dzuhayatin, Islam, Kepemimpinan Non-Muslim dan Hak Asasi Manusia, dalam Fikih Kebinekaan (Ma'arif Institute dan Mizan : Bandung), 302-303.
} 
Penolakan yang sudah lama muncul tersebut semakin menguat setelah tersebarnya postingan video dan "transkip" pidato Ahok di Kepulauan Seribu pada 27 September 2016 yang salah satu isinya dinilai melecehkan Islam. Kemudian MUI mengelurakan Pendapat dan Sikap Keagamaan MUI tentang Penistaan Agama, Penghinaan pada Ulama dan Penodaan Al-Qur'an oleh Ahok pada 11 Oktober 2016 yang di antaranya menyatakan bahwa "pernyataan Gubernur DKI Jakarta dikategorikan: (1) Menghina Al-Qur'an dan atau (2) menghina ulama yang memiliki konsekuensi hukum". Setelah keluarnya Pendapat dan Sikap, yang sering dipahami sebagai fatwa, inilah lantas muncul GNPF-MUI (Gerakan Nasional Pengawal Fatwa MUI) yang kemudian menjadi motor Aksi Bela Islam. ${ }^{4}$

Menurut Iqbal Ahnaf, atmosfer bela Islam yang terpusat di Jakarta telah menyebar ke berbagai penjuru di Indonesia. Dalam suatu khutbah jum'at yang ia ikuti, materi yang khotib sampaikan menyinggung isu kepemimpinan non-Muslim dan tuduhan penodaan-penodaan terhadap Islam oleh Gubernur DKI Jakarta, Basuki Tjahja Purnama. Bahkan lebih dari sekedar melarang untuk memilih non-Muslim sebagai pemimpin, khotib juga berseru tentang larangan berteman dengan non-Muslim. Demikian makna surat Al-Maidah ayat 51 yang dipahaminya, ia mengatakan "mereka (non-Muslim) dijadikan teman saja tidak boleh apalagi menjadi pemimpin." 5

Fenomena seperti itu marak terjadi di berbagai masjid hingga pengajian. Otoritas penfsiran yang seharusnya tidak dimiliki sembarang orang telah berubah. Semua orang merasa berhak menafsirkan dan memahami ayat tersebut dengan pemahamannya sendiri. Sehingga tak heran, berbagai tafsir yang tersebar berupa tafsir "intoleran" yang bersifat sentimen kepada kelompok lain. Oleh sebab itu, tulisan ini hendak mendiskusikan bagaimana padangan dua Mufassir Indonesia, yaitu Hamka dan M. Quraish Shihab mengenai surat Al-Maidah ayat 51. Apakah ada perbedaan antara kedua tokoh ini, serta apa yang melatarbelakangi perbedaan tersebut.

\section{Sketsa Biografis-Akademis Dua Mufassir}

Hamka (Haji Abdul Malik Karim Amrullah) adalah keturunan dari suku Tanjung yang berasal dari keluarga Abdul Arief, seorang pahlawan Paderi yang bergelar Tuanku Pauh Pariaman atau Tuanku Nan Tuo. ${ }^{6}$ Hamka lahir di Sungai Batang, Maninjau, pada tanggal 17 Februari 1908 bertepatan dengan 14 Muharram 1326 Hijriyah. Ayahnya adalah salah seorang Ulama tersohor di Minangkabau, yaitu Haji Abdul Karim Amrullah. Sedangkan ibunya bernama Siti Safiyah adalah anak dari Gelanggang gelar Baginda Nan Batuah. ${ }^{7}$

\footnotetext{
${ }^{4}$ Ahmad Najib Burhani, Aksi Bela Islam: Konservatisme dan Fragmentasi Otoritas Keagamaan dalam Jurnal Ma'arif, hlm. 18

${ }^{5}$ Mohammad Iqbal Ahnaf, "Aksi Bela Islam", Akankah Mengubah Lanskap Muslim Indonesia? Dalam Jurnal Ma'arif, hlm. 30-31

${ }^{6}$ Hamka, Ayahku: Riwayat Hidup Dr. H. Abdul Karim Amrullah dan Perjuangan Kaum Agama di Sumatera (Jakarta: Yayasan Uminda, 1982), 36.

${ }^{7}$ Nasir Tamara, dkk, hamka di Mata Hati Umat (Jakarta: Pustaka Sinar Harapan, 1996), 51.
} 
Prof. Dr. Buya Haji Abdul Malik bin Abdul Karim Amrullah atau lebih dikenal di kalangan muslim Indonesia dengan sebutan Buya HAMKA yang diambil dari akronim namanya. Ia dikenal sebagai seorang yang otodidak atau belajar sendiri. ${ }^{8}$ Sejak kecil, ia gemar membaca, baik bacaan tentang agama ataupun bacaan tentang cerita-cerita daerah. Hingga ayahnya pernah memberinya pilihan untuk menjadi orang yang alim atau menjadi tukang cerita. ${ }^{9}$ Hampir seluruh pendidikan yang didapatnya ialah berasal dari ayahnya yang notabene sebagai ahli agama di daerahnya. Dalam pendidikan formal, Hamka hanya sampai pada kelas tiga sekolah desa dan sekolah agama yang ia jalani di Padang Panjang dan Parabek juga hanya tiga tahun. Kendati demikian, dengan semangat keilmuannya, ia melanglangbuana ke berbagai daerah untuk mencari ilmu secara informal. ${ }^{10}$

Di usia ke 16, Hamka telah meninggalkan Minangkabau menuju Yogyakarta. di sana ia berkenalan dan menimba ilmu tentang pergerakan kepada para aktivis Islam, seperti HOS Tjokroaminoto (Sarekat Islam), Ki Bagus Hadikusumo (Muhammadiyah) dan beberapa tokoh lainnya. Hamka juga menjadi anggota Sarekat Islam pada saat itu. Hingga pada pertengahan 1925, Hamka kembali ke Padang Panjang dan mendirikan Muhammadiyah di rumah ayahnya. ${ }^{11}$ Dua tahun setelah kembalinya dari Jawa, Hamka pergi menunaikan Haji ke Mekkah. Kesempatan tersebut, ia gunakan untuk memperluas pengetahuan dan pengalamannya. Di Mekkah, Hamka bekerja di sebuah percetakan selama enam bulan. Setelah itu, dia kembali ke Indonesia dan mulai aktif dalam dunia yang dia tekuni, baik sebagai tokoh agama, aktivis, politisi dan sastrawan.

Pada 1928, Hamka menghadiri Muktamar Muhammadiyah di Solo. Sekembalinya dari muktamar tersebut, Hamka mulai memangku beberapa jabatan penting di Muhammadiyah, sampai pada akhirnya dia diangkat sebagai Ketua Umum Pimpinan Muhammadiyah dalam Muktamar Muhammadiyah ke-32 di Purwokerto pada tahun 1953.12 Setahun sebelumnya, ketika Hamka menjadi pejabat tinggi dan penasihat Depag, pemerintah Amerika Serikat pernah mengundangnya untuk menetap selama empat bulan. Selama kunjungan tersebut, Hamka mempunyai pandangan yang lebih terbuka terhadap negara-negara non-Islam. Sekembalinya dari Amerika Serikat, Hamka menerbitkan buku perjalanannya Empat Bulan di Amerika Serikat sebanyak dua jilid. Sesudah itu, secara berturut-turut, Hamka menjadi anggota misi kebudayaan ke Muangthai (1953), mewakili Depag menghadiri peringatan mangkatnya Budha di Birma (1954), menghadiri konferensi Islam di Lahore (1958) dan menghadiri undangan Universitas Al-Azhar Kairo untuk memberikan ceramah tentang

\footnotetext{
${ }^{8}$ M. Bibit Suprapto, Ensiklopedia Ulama Nusantara (Jakarta: Gelagar Media Indonesia), 333.

${ }_{9}^{9}$ Nasir Tamara, dkk, hamka di Mata Hati Umat (Jakarta: Pustaka Sinar Harapan, 1996), 368.

${ }^{10}$ M. Bibit Suprapto, Ensiklopedia Ulama Nusantara (Jakarta: Gelagar Media Indonesia), 334.

11 A. Susanto, Pemikiran Pendidikan Islam (Jakarta: Amzah, 2009), 98.

12 Shobahussurur, Mengenang 100 Tahun Haji Abdul Malik Karim Amrullah, Hamka (Jakarta: Yayasan Pesantren Islam al-Azhar, 2008), 24.
} 
pengaruh Muhammad Abduh di Indonesia. Ceramah tersebut menghasilkan gelar Doktor Honoris Causa bagi Hamka. ${ }^{13}$

Selain aktif di Muhammadiyah dan Depag, Hamka juga dikenal aktif dalam dunia politik. Ia merupakan salah satu anggota di Partai Masyumi setelah kemerdekaan Indonesia. Hingga pada tahun 1955, dalam pemilihan umum, Hamka terpilih sebagai Dewan Konstituante mewakili Jawa Tengah. ${ }^{14}$ Di Kostituante, Hamka dengan Mohammad Natsir adalah pihak yang paling keras dan konsisten untuk mempejuangkan syariat Islam menjadi dasar Negara Indonesia. Namun, jerih payah yang digagas dengan rekan-rekannya itu kandas, setelah Soekarno membubarkan Dewan Konstituante pada 5 Juli 1959.

Setelah dekrit pembubaran tersebut, bisa dikatakan perjalanan Hamka dalam dunia politik telah selesai, karena partai yang ia gawangi dibubarkan oleh Presiden Soekarno. Sikapnya yang keras mengenai agama, sering berbenturan dengan beberapa kebijakan pemerintah dan hal itu membuatnya dipenjarakan oleh Presiden Soekarno pada tahun 1964 hingga 1966. ${ }^{15}$ Selama berada di tahanan, Hamka menyelesaikan Tafsir Al-Azhar sebanyak tiga puluh jilid. ${ }^{16}$ Setelah Hamka dibebaskan dari penjara, pada tahun 1977, ia terpilih sebagai ketua umum Majelis Ulama Indonesia yang pertama. Jabatan tersebut diembannya hingga pertengahan 1981. ${ }^{17}$ Ia memundurkan diri dari jabatan tersebut karena fatwa yang dikeluarkan MUI mengenai keharaman merayakan Natal untuk muslim tidak dipedulikan oleh pemerintah. Bahkan Alamsyah Ratu, Menteri Agama pada saat itu mengecam fatwa tersebut dan meminta untuk dicabut. ${ }^{18}$

Pada tanggal 24 Juli 1981, dua bulan setelah Hamka memundurkan diri dari jabatan ketua umum Majelis Ulama Indonesia (MUI), ia meninggal di usia 73 tahun. ${ }^{19}$ Ia meninggalkan berbagai karya yang ia tulis di tengah-tengah kesibukannya, baik sebagai tokoh agama, pegawai pemerintahan hingga politisi, antara lain : Di Bawah Lindungan Ka'bah, Tasawuf

${ }^{13}$ Yunan Yusuf, Corak Pemikiran Kalam Tafsir Al-Azhar (Jakarta: Pustaka Panjimas, 1990), 48-49.

${ }^{14}$ Hery Muhammad, dkk, Tokoh-tokoh Islam yang berpengaruh Abad 20 (Jakarta: Gema Insani Press, 2006), 57.

${ }^{15}$ Hery Muhammad, dkk, Tokoh-tokoh Islam yang berpengaruh Abad 20 (Jakarta: Gema Insani Press, 2006), 57.

16 Achmad Syahrul, Penafsiran Hamka tentang Syura dalam Tafsir al-Azhar (Fakultas Ushuluddin dan Pemikiran Islam, 2009), 22.

${ }^{17}$ Hery Muhammad, dkk, Tokoh-tokoh Islam yang berpengaruh Abad 20 (Jakarta: Gema Insani Press, 2006), 60.

18 Yunan Yusuf, Corak Pemikiran Kalam Tafsir Al-Azhar (Jakarta: Pustaka Panjimas, 1990), 52-53.

${ }_{19}$ Yunan Yusuf, Corak Pemikiran Kalam Tafsir Al-Azhar (Jakarta: Pustaka Panjimas, 1990), 52-53. 
Modern, Negara Islam, Tenggelamnya Kapal Van Der Wijk, Islam dan Demokrasi, Tafsir Al-Azhar dan karya-karya lainnya. ${ }^{20}$

Sementara itu, M. Quraish Shihab lahir di Rappang Sulawesi Selatan, pada tanggal 16 Februari 1944. ${ }^{21}$ Beliau berasal dari keturunan Arab yang terpelajar. Ayahnya bernama Abdurrahman Shihab (1905-1986) adalah alumni Jam'iyyah al-Khair Jakarta, sebuah lembaga pendidikan Islam tertua di Indonesia yang mengedepankan gagasan-gagasan Islam modern. Selain sebagai guru besar tafsir, sang ayah juga pernah menjabat sebagai Rektor di IAIN Alaudin Ujung Pandang dan tercatat sebagai salah seorang pendiri Universitas Muslim Indonesia (UMI) Ujung Pandang.

Sebagai putra dari seorang tokoh dalam dunia pendidikan, terutama bidang tafsir, $\mathrm{M}$. Quraish Shihab mendapatkan motivasi awal dan benih kecintaan terhadap al-Qur'an dari ayahnya. Sejak umur enam hingga tujuh tahun, ia selalu mengikuti pengajian al-Qur'an yang diadakan oleh ayahnya sendiri.22 Selain itu, seringkali sang ayah mengajak anak-anaknya duduk bersama, sembari menyuruh mereka membaca al-Qur'an dan kemudian akan diuraikan mengenai kisah-kisah dalam al-Qur' an oleh sang ayah. Pada saat-saat seperti inilah, sang ayah menyampaikan berbagai petuah keagamaannya. Banyak petuahnya itu yang kemudian baru disadari M. Quraish Shihab sebagai ayat al-Qur'an, sabda nabi, petuah sahabat atau para pakar tafsir al-Qur'an yang cukup membekas di hatinya. ${ }^{23}$

Pendidikan formalnya dimulai dari sekolah dasar di Ujung Pandang, kemudian melanjutkan Sekolah Lanjutan Tingkat Pertama (SLTP) di Malang sambil nyantri di Pondok Pesantren Darul Hadis al-Falaqiyyah. Untuk lebih mmendalami studi keislaman, Shihab dikirim oleh ayahnya ke al-Azhar, Kairo pada tahun 1958 dan diterima di kelas dua Tsanawaiyah. Setelah itu, ia melanjutkan studinya di Universitas Al-Azhar Kairo Mesir pada Fakultas Ushuluddin, Jurusan Tafsir dan Hadis. Ia meraih gelar L.c. pada tahun 1967. Dua tahun kemudian, pada tahun 1969, M. Quraish Shihab berhasil meraih gelar MA pada jurusan yang sama dengan tesis al-I'jaz al-Tashri' li al-Qur'an al-Karim. ${ }^{24}$

Pada tahun 1973, ia dipanggil pulang ke Ujung Pandang oleh ayahnya, yang pada saat itu menjabat sebagai rektor, untuk membantu mengelola pendidikan di IAIN Alaudin. M. Quraish Shihab dijadikan wakil rektor bidang akademis dan kemahasiswaan sampai 1980.

\footnotetext{
${ }^{20}$ Nasir Tamara, dkk, hamka di Mata Hati Umat (Jakarta: Pustaka Sinar Harapan, 1996), 142.

${ }^{21}$ M. Quraish Shihab, Membumikan Al-Qur'an, Fungsi dan Peran Wahyu dalam Kehidupan Masyarakat (Bandung : PT Mizan Pustaka, 2009), 7.

${ }^{22}$ Muhammad Dian Supyan, "Kepemimpinan Islam dalam Tafsir Al-Misbah Karya M. Quraish Shihab", Skripsi Fak. Dakwah UIN Sunan Kalijaga 2013.
}

${ }^{23}$ M. Quraish Shihab, Membumikan Al-Qur'an, Fungsi dan Peran Wahyu dalam Kehidupan Masyarakat (Bandung : PT Mizan Pustaka, 2009), 14.

${ }^{24}$ IRCR, Islam dan Urusan Kemanusiaan, Konflik, Perdamaian dan Filantropi (Jakarta: Serambi, 2015), 169. 
Selain menduduki jabat tersebut, ia seringkali menggantikan ayahnya yang $u z u r$ karena usia dalam mengurusi beberapa tugas tertentu. Berturut-turut, M. Quraish Shihab diserahi berbagai jabatan, seperti Koordinator Perguruan Tinggi Swasta wilayah VII Indonesia bagian timur dalam bidang pendidikan mental dan sederet jabatan lainnya di luar kampus. Di selasela kesibukannya, ia masih sempat merampungkan beberapa tugas penelitian, antara lain Penerapan Kerukunan Hidup Beragama di Indonesia (1975) dan Masalah Wakaf Sulawesi Selatan $(1978){ }^{25}$

Kemudian pada tahun 1980, Shihab kembali ke Mesir untuk melajutkan studinya di bidang yang sama dan alamater yang sama, Univesitas Al-Azhar Kairo. Dua tahun setelahnya, dengan disertasinya berjudul Nazm ad-Durar li al-Biqa'i Tahqiq wa Dirasah, ia meraih gelar doktor di bidang ilmu-ilmu al-Qur'an dengan yudisium Summa Cum Laude disertai penghargaan Tingkat I (mumtaz ma'a martabat al-sharaf al-ula). Ia menjadi orang pertama di Asia Tenggara yang meraih gelar doktor dalam Ilmu-ilmu Al-Qur'an di Universitas Al-Azhar Kairo Mesir. ${ }^{26}$ Sekembalinya ke Indonesia, Shihab tidak lagi mengajar di IAIN Alaudin, ia dipindahtugaskan ke Fakultas Ushuluddin IAIN Syarif Hidayatullah (sekarang UIN) Jakarta. Kemudian, karena keahliannya dalam bidang kajian al-Qur'an, ia dipercaya untuk menjadi Rektor IAIN Syarif Hidayatullah Jakarta (sekarang UIN) selama dua periode (1992-1996 dan 1997-1998). Selain dalam bidang akademis, ia juga berkiprah di Majelis Ulama Indonesia (Pusat) sebagai ketua pada tahun 1985-1998; anggota MPR-RI 1982-1987 dan 1987-2002; dan pada 1998, dipercaya menjadi Menteri Agama RI. ${ }^{27}$ Aktivitas uatamanya sekarang adalah selain sering tampil di berbagai media untuk memberikan siraman ruhani dan intelektual juga sebagai Guru Besar Pasca Sarjana UIN Syarif Hidayatullah Jakarta dan Direktur Pusat Studi Al-Qur'an (PSQ) Jakarta.28

Di sela-sela kesibukannya, Shihab juga terlibat berbagai kegiatan ilmiah dalam maupun luar negeri. Yang tidak kalah pentingnya, Shihab juga juga aktif dalam kegiatan tulis-menulis dalam rubrik "Pelita Hati", dia juga mengasuh rubrik "Tafsir Al-Amanah" dalam majalah dua mingguan yang terbit di Jakarta. Beberapa buku yang sudah ia hasilkan, antara lain adalah Membumikan Al-Qur'an, Wawasan Al-Qur'an; Tafsir Maudhu'i atas Pelbagai Persoalan Umat, kedua buku ini merupakan buku bestseller, yang pertama terjual lebih dari 75 ribu kopi dan yang kedua hingga tahun 2000 sudah dicetak sebanyak 11 cetakan $^{29}$, di samping masih

${ }^{25}$ Hasan Muarif Ambarity (Dewan Redaksi), Supelemen Ensiklopedi Islam (Jakarta: Ichtar Baru Von Hoeve, 2004), 111.

${ }^{26}$ M. Quraish Shihab, Lentera Al-Qur'an: Kisah dan Hikmah Kehidupan (Bandung: PT Mizan Pustaka, 2014), 5.

${ }^{27}$ M. Quraish Shihab, Lentera Al-Qur'an: Kisah dan Hikmah Kehidupan (Bandung: PT Mizan Pustaka, 2014), 5 .

${ }^{28}$ M. Quraish Shihab, Secercah Cahaya Ilahi (Jakarta: Lentera Hati, 2007), 6.

${ }^{29}$ IRCR, Islam dan Urusan Kemanusiaan, Konflik, Perdamaian dan Filantropi (Jakarta: Serambi, 2015), 170. 
banyak karya M. Quraish Shihab yang lain yang menjadi rujukan masyarakat Muslim di Indonesia, seperti Tafsir Al-Misbah. ${ }^{30}$

\section{Penafsiran Surat Al-Maidah Ayat 51}

Dalam Tafsir Al-Azhar, Hamka mengartikan surat Al-Maidah ayat 51 sebagai berikut:

"Wahai orang-orang yang beriman! Janganlah kamu mengambil orang Yahudi dan Nasrani menjadi pemimpin-pemimpin; sebagian mereka adalah pimpinan-pimpinan dari yang sebagian. Dan barang siapa menjadikan mereka pemimpin di antara kamu, maka sesungguhnya dia itu telah tergolong dari mereka. Sesungguhnya Allah tidaklah akan memberi petunjuk kepada kaum yang zalim."

Kemudian ia menjelaskan bahwa bagi orang-orang yang beriman, sudah menjadi konsekwensi dari keimanannya, untuk tidak menyerahkan kepemimpinan kepada orangorang Yahudi, Nasrani atau orang-orang yang tidak seharusnya mengetahui rahasia orang mukmin, karena hal demikian tidak akan bisa menyelesaikan permasalahan melainkan akan menimbulkan masalah lainnya.

Lebih lanjut, Hamka menjelaskan dalam ayat tersebut, penyebutan golongan dengan menggunakan Yahudi dan Nasrani, bukan Ahlul kitab ialah disebabkan, menurut para ahli tafsir, dalam pokok ajaran kitab-kitab mereka tidak ada ajaran yang menentang ajaran Tauhid yang dibawa oleh Nabi Muhammad SAW, terlepas dari paham $t a^{\prime} a s h u b$ (fanatisme), kitabkitab terdahulu tidak berlawanan dengan Al-Qur'an. Namun, di kemudian har setelah adanya fanatisme, maka ajaran yang sesuai dengan Islam pun ditinggalkan. ${ }^{31}$

Menjadikan orang-orang Yahudi dan Nasrani sebagai pemimpin, sekalipun sebagain kecil saja, mereka akan tetap berdekatan dengan orang-orang yang sepaham dengan dirinya. Mereka melakukan tugas sebagai pemimpin tidaklah sepenuh hati karena mereka tetap mengikuti asal-usul mereka, yaitu memusuhi Islam. Dalam masalah kepercayaan, antara Yahudi dan Nasrani sangatlah berbeda. Orang-orang Yahudi menganggap Maryam telah melakukan zina dan Isa bukanlah anak Tuhan. Orang-orang Yahudi memusuhi orang-orang Nasrani dan begitu juga sebaliknya. Namun, ketika mereka hendak menghadapi Islam, sebenci apapun satu sama lain. Mereka akan saling bant-membantu dalam urusan ini. ${ }^{32}$ Kemudian Hamka memperkuat penjelasannya dengan memberikan argumentasi historis :

"Sebagaimana pernah terjadi di Bandung pada masa Republik Indonesia telah memilih Anggota Badan Konstituante. Wakil-wakil pertai-partai Islam ingin agar di dalam Undang-undang Dasar yang akan dibentuk itu dicantumkan tujuh kalimat, yaitu: "Dengan kewajiban menjalankan syariat

\footnotetext{
30 Tafsir Al-Qur'an lengkap 30 juz yang ditulis oleh M. Quraish Shihab dan pertama kali dicetak pada tahun 2000. Tafsir ini ditulis dengan susuan mushaf (tartib mushafi) dengan halaman lebih dari 10.000 halaman terdiri dari 15 Volume besar.

${ }^{31}$ Hamka, Tafsir Al-Azhar, Jilid 3 (Singapura: Kerjaya Print, 2007), 1761

${ }^{32}$ Hamka, Tafsir Al-Azhar, Jilid 3 (Singapura: Kerjaya Print, 2007), 1761-1762
} 
Islam bagi pemeluknya." Maka seluruh partai yang membenci cita-cita Islam itu sokong-menyokong, pimpin-memimpin, beri-memberi, menentang cita-cita itu, walaupun di antara satu sama lain berbeda ideologi dan berbeda kepentingan. Dalam menghadapi Islam, mereka bersatu. Bersatu Katholik, Protestan, partai-partai Nasional, pasrati Sosialis dan partai Komunis."

Dalam gelanggang Internasional pun begitu pula. Pada tahun 1964, Paus Paulus VI, sebagai Kepala Tertinggi dari gereja Katholik mengeluarkan ampunan umum bagi agama Yahudi. Mereka dibebaskan dari dosa yang selama ini dituduhkan kepada mereka, yaitu karena usaha merekalah Nabi Isa Almasih ditangkap oleh Penguasa Romawi dan diserahkan kepada orang Yahudi, lalu disalib (menurut kepercayaan mereka).

Sekarang setelah 20 Abad, Yahudi dikutuk, Yahudi dihina di mana-mana dalam dunia Kristen, tibatiba Paus memberikan mereka ampun.

Ampun apakah ini, sehingga pegangan kepercayaan 2.000 tahun dapat dirubah demikian saja?

Tidak lain adalah "Ampunan Politik". Tenaga Yahudi yang kaya raya dengan uang harus bersatu padu dengan Kristen di dalam menghadapi bahaya Islam. Kemudian, 1967, negeri-negeri Arab diserang Yahudi dalam masa empat hari dan Jerusalem (Baitul Maqdis) dirampas dari tangan kaum muslimin, wilayah turun temurun selama 1.300 tahun lebih dari bangsa Arab supaya diserahkan kepada satu Badan Internasional. Tegasnya kepada PBB, sedang yang berkuasa penuh dalam PBB itu adalah negara-negara Kristen. (Perancis Katholik, Amerika protestan, Inggeris Anglicant dan Rusia Komunis). ${ }^{33}$

Pada zaman Nabi Muhammad, di Madinah tidak tampak bahu-membahu seperti peristiwa di atas, karena agama Yahudi merupakan agama terbesar di Madinah pada saat itu, selain Islam. Sedangkan agama Nasrani berkembang di masyarakat Syam (utara) dan Najran Yaman (selatan). Kemudian Hamka menyatakan bahwa keajaiban Al-Qur'an dapat dirasakan dengan perjalanan sejarah. Dua agama yang awalnya bermusuhan, yaitu Yahudi dan Nasrani, di kemudian hari saling membantu dan akhirnya Negara Israel dapat berdiri di tengahtengah negara Islam, dengan bantuan para pemeluk Krsiten. Mereka tidak lagi mempermasalahkan kepercayaan mereka yang saling bertentangan. Akan tetapi mereka lebih memilih saling mendukung dan membantu untuk melawan Islam yang menentang kepercayaan Yahudi bahwa Isa adalah anak zina dan kepercayaan Kristen yang mempercayai Isa adalah anak Tuhan. ${ }^{34}$

Suku kata selanjutnya adalah "Dan barang siapa yang menjadikan mereka itu pemimpin di antara kamu, maka sesungguhnya dia itu telah termasuk golongan dari mereka." Maksud dari penggalan ayat ini ialah tidak mungkin seorang yang menjadikan orang lain sebagai pemimpinnya tidak menyukainya atau tidak berempati kepadanya. Namun meskipun demikian, kendati demikian kesukaannya kepada orang yang berbeda agama tidak resmi membuatnya keluar dari agamanya. Kemudian Hamka mengutip perkataan Hudzaifah bin al-Yaman, salah satu sahabat Nabi yang pernah menjadi perwira perang: "Hati-hati tiap-tiap seseorang daripada kamu,

\footnotetext{
${ }^{33}$ Hamka, Tafsir Al-Azhar, Jilid 3 (Singapura: Kerjaya Print, 2007), 1762

${ }^{34}$ Hamka, Tafsir Al-Azhar, Jilid 3 (Singapura: Kerjaya Print, 2007), 1762-1763
} 
bahwa dia telah menjadi Yahudi dan Nasrani, sedang dia tidak merasa." ${ }^{35}$ Kemudian dibacakan ayat ini, yaitu kalau orang telah menjadikan mereka itu jadi pemimpin, maka dia telah termasuk golongan orang yang diangkatmya jadi pemimpin itu. ${ }^{36}$

Dalam sejarah kolonialisasi Kristen di negara-negara berpenduduk muslim, hal yang pertama kali dilakukan oleh penjajah adalah mengajarkan bahasa mereka, supaya orang-orang muslim yang terjajah berpikir dengan bahasa bangsa yang menjajah. Lalu mereka akan mulai lemah dalam bahasa sendiri dan terpengaruh dengan peradaban dan kebudayaan bangsa penjajah (Kristen). Dengan siringnya waktu, identitas mereka akan semakin hilang, cara berpikir dan pekembangan bahasanya juga. Sehingga mereka akan berpandangan bahwa bangsa penjajah memiliki martabat yang lebih tinggi ketimbang mereka. Hal ini seperti yang pernah dialami Indonesia yang dijajah Belanda, Afrika Utara yang dijajah Perancis, Tanah Melayu (Malaysia) dan India yang dijajah oleh Inggris. Oleh sebab itu, akan lebih sulit menjelaskan ajaran agama kepada pribumi yang sudah terkontaminasi pikirannya daripada orang Amerika atau Eropa yang hendak memeluk Islam. ${ }^{37}$

Selanjutnya Hamka megkritik orang-orang pribumi yang menamakan dirinya sebagai "orang intelek" yang meminta keterangan agama yang "masuk akal". Hal ini tentu disebabkan oleh didikan para penjajah yang menanamkan keraguan dalam segala hal, termasuk agama yang dianutnya. Bisa jadi, akal mereka memang cerdas dan rasional, akan tetapi jiwa pada diri mereka telah berubah. Segala hal baik hanyalah berasal dari negara para penjajah, sedangkan segala yang terlahir dari agama dan negerinya dianggap buruk dan kaku. Hamka mengutip penyataan Ibnu Khaldun dalam Muqaddimahnya bahwa orang-orang yang kalah cenderung meniru orang yang mengalahkannya, baik dalam simbol, cara berpakaian, kebiasaan hingga adat-istiadatnya. Sebab orang-orang yang kalah percaya bahwa kesempurnaan hanya ada pada orang-orang yang telah mengalahkannya. ${ }^{38}$ Sehingga mereka hanya menjalankan syariat agamanya dan melupakan kahikat agamanya.

Lebih lanjut Hamka menjelaskan bahwa menjadikan para penjajah (Kristen) sebagai pemimpin akan berimplikasi orang-orang yang dijajah tidak akan keberatan untuk menjual agama dan negaranya. Hamka mengisahkan ketika Belanda mulai kewalahan dalam menghadapi rakyat Aceh yang tetap memepertahankan kemerdekaan, maka didatangkan salah seorang jaksa yang beragama Islam dari luar Aceh. Dia memberikan arahan dalam upaya megalahkan rakyat Aceh pada saat itu dan pada akhirnya Aceh dapat dikalahkan oleh Belanda. Konon seorang jaksa tersebut adalah orang yang taat dalam beragama da dia mendapatkan bintang Willemsorde dari Belanda atas jasanya dalam mengalahkan rakyat Aceh yang satu agama dengannya.

\footnotetext{
وليتق احدكم ان يكون يهوديا أو نصر انيا وهو لا يشعر 35

${ }^{36}$ Hamka, Tafsir Al-Azhar, Jilid 3 (Singapura: Kerjaya Print, 2007), 1763

${ }^{37}$ Hamka, Tafsir Al-Azhar, Jilid 3 (Singapura: Kerjaya Print, 2007), 1763

${ }^{38}$ Hamka, Tafsir Al-Azhar, Jilid 3 (Singapura: Kerjaya Print, 2007), 1764
} 
Pada suku kata terakhir, yaitu "Sesungguhnya Allah tidaklah akan memberi petunjuk kepada kaum yang zalim." Dapat dipahami bahwa menjadikan orang-orang Yahudi dan Nasrani sebagai pemimpin merupakan suatu tindakan zalim atau aniaya. Adapun kata zalim (ظالم) ialah berasal dari kata zulm (ظلم) yang berarti gelap. Oleh sebab itu, mereka digolongkan sebagai orang yang memilih jalan yang gelap, sehingga cahaya penerang tidak diberikan oleh Allah.

Hamka berpendapat bahwa surat Al-Maidah ayat 51 ini dengan jelas melarang orang-orang yang beriman menjadikan orang-orang Yahudi dan Nasrani sebagai pemimpin. Akan tetapi jikalau hanya sekedar menjadikan mereka partner dalam urusan perekonomian ataupun sosial tidaklah menjadi masalah. Dalam surat al-Hujurat ayat 13 :

"Wahai manusia! Sesungguhnya telah Kami ciptakan kamu itu dari seorang laki-laki dan seorang perempuan, dan telah Kami jadikan kamu berbangsa-bangsa dan bersuku-suku, supaya kamu kenalmengenal. Seungguhnya kaum yang paling mulia di sisi Tuhan ialah yang paling takwa kepadaNya. Sesungguhnya Allah adalah Maha Tahu dan Maha Mengerti."

Dalam permasalahan ekonomi, Rasulullah pernah menggadaikan perisainya kepada tetangganya, seorang Yahudi. Selain itu, Rasulullah pernah menyembelih seekor kambing dan memerintahkan salah satu sahabat untk mengantarkannya kepada tetangganya yang Yahudi. Kemudian dalam hukum Islam, seorang lelaki muslim dapat menikah dengan seorang perempuan dari Ahli Kitab, karena dalam bahtera rumah tangga, seorang suami adalah pemimpin dalam keluarga. Akan tetapi seorang perempuan muslim tidak dapat menikah dengan lelaki Ahli Kitab, kecuali lelaki tersebut memeluk Islam terlebih dahulu. ${ }^{39}$

Sedangkan dalam urusan pemerintaha, Penguasa Islam diperbolehkan memberikan kepercayaan kepada pemeluk agama lain untuk menduduki jabatan penting dalam pemerintahan. Kebolehan ini beradasarkan bahwa pimpinan tertinggi ada di tangan Islam, sehingga tidak perlu ditakutkan terhadap adanya pemberontakan ataupun penyelewangan amanah. Namun, jikalau dikhawatirkan akan terjadi sesuatu yang tidak diinginkan, maka pemberian jabatan tersebut tidak diperbolehkan. ${ }^{40}$

Setelah panjang lebar memberikan penafsiran pada ayat 51 surat Al-Maidah, Hamka memberikan suatu penjelasan mengenai sabab nuzul ayat ini. Ia menyatakan bahwa ada beberapa riwayat yang berbeda perihal turunnya ayat ini. Salah satunya ialah mengenai penghianatan orang-orang Yahudi dari bani Nadhir. Disebutkan bahwa penduduk Arab Madinah, yaitu dari suku Khazraj dan Aus, sebelum memeluk Islam, telah membuat perjanjian dengan suku Yahudi yang ada di Madinah, yaitu Bani Nadhir, Quraizhah dan Qainuqa', untuk saling bantu-membantu. Setelah suku Khazraj dan Aus memeluk Islam dan Nabi Muhammad hijrah ke Madinah, sebuah perjanjian untuk hidup berdampingan dengan damai antara Islam dan Yahudi pun dilakukan. Apabila Madinah diserang, maka mereka

\footnotetext{
${ }^{39}$ Hamka, Tafsir Al-Azhar, Jilid 3 (Singapura: Kerjaya Print, 2007), 1765

${ }^{40}$ Hamka, Tafsir Al-Azhar, Jilid 3 (Singapura: Kerjaya Print, 2007), 1766
} 
harus saling membantu. Selain itu, Nabi Muhammad juga memberikan jaminan kebebasan kepada mereka dalam memeluk agama.

Namun selang beberapa lama, salah satu suku Yahudi, yaitu bani Nadhir melakukan penghianatan dengan hendak merencanakan pembunuhan terhadap Nabi Muhammad ketika berkunjung ke desa mereka. Akan tetapi upaya tersebut gagal. Sehingga dengan beberapa bukti, suku tersebut dikepung oleh orang-orang Islam dan kemudian mengusir mereka dari tempat tersebut. selain itu, penghianatan juga dilakukan oleh suku yang lain, yaitu orang-orang Yahudi dari bani Quraizah dalam peperangan Al-Ahzab (perang Khandzaq) dengan membocorkan kekuatan orang-orang Islam kepada kaum musyrik Mekkah. Karena telah melanggar perjanjian yang telah disepakati, maka orang-orang Yahudi dari bani Quraidzah dihukum, seluruh lelaki dibunuh, anak dan istrinya dijadikan tawanan serta harta bendanya dirampas. Beberapa penghianatan tersebut menjadi salah satu riwayat sabab nuzul ayat ini. ${ }^{41}$

Meskipun terdapat beberapa riwayat mengenai sabab nuzul ayat ini, Hamka berpendapat bahwa yang dijadikan pedoman adalah isi dari ayat tersebut. Pendapat ini diperkuat dengan salah satu kaedah Ushul Fiqh: "Yang dipandang adalah umum maksud perkataan, bukanlah sebab yang khusus." Artinya, yang dijadikan pegangan adalah maksud dan tujuan dari perkataan (lafadz), bukan tentang sabab turunnya ayat. Sehingga larangan ini berlaku salamanya demi menjaga ajaran Islam. ${ }^{42}$

Sementara itu, dalam Tafsir Al-Misbah, salah satu ciri penafsiran yang dilakukan oleh M. Quraish Shihab ialah penguraian arti kata perkata dalam suatu ayat dengan sangat mendetail, sehingga dapat diperoleh suatu pemahaman yang luas mengenai kata pada ayat yang hendak ditafsirkan. Berbeda dengan Hamka dalam mengartikan surat Al-Maidah ayat 51, M. Quraish Shihab tidak mengartikan kata auliya' dengan pemimpin seperti yang dilakukan Hamka dalam Tafsir Al-Azhar. Shihab lebih memilih untuk tetap menuliskan kata auliya' dalam terjemahannya. Karena baginya, kata auliya' tidak hanya berarti pemimpin.

M. Quraish Shihab tidak begitu sependapat dengan penerjemahan kata auliya' dengan pemimpin-pemimpin yang dilakukan oleh Tim Departemen Agama dalam Al-Qur'an dan Terjemahnya. Ia berpendapat bahwa penerjemahan tersebut tidaklah sepenuhnya tepat. Lebih lanjut, Shihab menjelaskan bahwa kata (أولياء) auliya' adalah bentuk jamak dari kata (ولي) waliy. Kata ini terambil dari akar kata yang terdiri dari huruf wauw, lam dan ya' yang makna dasarnya adalah dekat. Dari sini kemudian berkembang makna-makna baru, seperti pendukung, pembela, pelindung, yang mencintai, lebih utama, dan lain-lain, yang kesemuanya diikat oleh benang merah kedekatan. Itu sebabnya ayah adalah orang paling utama yang menjadi waliy anak perempuannya, karena dia adalah yang terdekat kepadanya. Orang yang amat taat dan tekun beribadah dinamai waliy karena dia dekat kepada Allah. Seorang yang

\footnotetext{
${ }^{41}$ Hamka, Tafsir Al-Azhar, Jilid 3 (Singapura: Kerjaya Print, 2007), 1766-1767

${ }^{42}$ Hamka, Tafsir Al-Azhar, Jilid 3 (Singapura: Kerjaya Print, 2007), 1767
} 
bersahabat dengan orang lain sehingga mereka selalu bersama dan saling menyampaikan rahasia karena kedekatan mereka, juga dapat dinamai waliy. ${ }^{43}$

Demikian juga pemimpin, karena dia seharusnya dekat kepada yang dipimpinnya. Demikian dekatanya sehingga dialah yang pertama mendengar peanggilan bahkan keluhan dan bisikan siapa yang dipimpinnya, dan karena kedekatannya itu dia pula yang pertama datang membantunya. Demikian terlihat bahwa semua makna-makna yang dikemukakan di atas dapat dicakup oleh kata auliya'.44

Selanjutnya M. Quraish Shihab mengutip pendapat salah seorang mufassir ternama dari Syi' ah, Thaba'thaba'i perihal kata auliya'. Menurut Thaba'thaba'i, kata auliya' memiliki makna sebagai sebuah kedekatan kepada sesuatu yang menjadikan terangkat dan hilangnya batas antara yang mendekat dan yang didekati dalam tujuan kedekatan itu. Dalam konteks ketakwaan dan pertolongan, kata auliya' bisa diartikan sebagai penolong-penolong. Apabila dalam pergaulan dan kasih sayang, maka auliya' berarti orang yang yang dicintai dan ketertarikan hanya ada pada dirinya seorang. Jikalau dalam konteks hubungan kekeluargaan, maka waliy bisa diartikan sebagai orang yang mewarisinya dan tidak ada yang dapat menghalangi pewarisan tersebut. sedangkan dalam konteks ketaatan, kata waliy berarti siapa yang memerintah dan harus ditaati ketetapannya. ${ }^{45}$

Sekilas memang ayat ini berkonotasi global, namun Thaba'thabai berkesimpulan bahwa kata auliya' yang dimaksud oleh ayat ini adalah cinta kasih yang mengantar kepada meleburnya perbedaan-perbedaan dalam satu wadah, menyatunya jiwa yang tadinya berselisih, saling terkaitnya akhlak dan miripnya tingkah laku, sehingga dua orang yang saling mencintai seakan-akan terlihat memiliki satu jiwa, satu kehendak dan satu perbuatan yang tidak akan berbeda satu sama lain. Kesimpulan ini dipertegas dengan bunyi ayat: "Barang siapa di antara kamu menjadikan mereka auliya', maka sesungguhnya dia termasuk sebagian mereka." Quraish Shihab menambahkan suatu pribahasa "Siapa yang mencintai satu kelompok, maka ia termasuk kelompok itu" dan "Seseorang akan bersama siapa yang dicintainya."

Masih berkaitan dengan pembahasan kedekatan cinta kasih, terdapat salah satu ayat AlQur'an yang juga membicarakannya, yaitu Q.S. Al-Mumtahanah [60]: 1, yang artinya:

"Hai orang-orang yang beriman, janganlah kamu menjadikan musuh-Ku dan musuh kamu sebagai auliya',kamu menyampaikan kepada mereka (berita-berita Nabi Muhammad), karena rasa cinta kasih; padahal ssungguhnya mereka telah ingkar kepada kebenaran yang datang kepadamu, mereka mengusir Rasul dan (mengusir) kamu karena kamu beriman kepada Allah, Tuhanmu." Kemudian pada ayat ke sembilan di surat yang sama, mereka disifati sebagai orang-orang yang zalim. "Dan barang siapa menjadikan mereka auliya', maka mereka itulah orang-orang yang zalim." (Q.S. Al-Mumtahanah [60]:

\footnotetext{
${ }^{43}$ M. Quraish Shihab, Tafsir Al-Misbah, Jilid 3 (Jakarta: Lentera Hati, 2002), 123

${ }^{44}$ M. Quraish Shihab, Tafsir Al-Misbah, Jilid 3 (Jakarta: Lentera Hati, 2002), 123

${ }^{45}$ M. Quraish Shihab, Tafsir Al-Misbah, Jilid 3 (Jakarta: Lentera Hati, 2002), 123-124
} 
9), hal ini sama dengan yang disebutkan oleh surat Al-Maidah[5]: 51: “Sesungguhnya Allah tidak memberi petunjuk kepada orang-orang yang zalim."

Kemudian M. Qurasih Shihab menjelaskan bahwa dalam ayat 51 surat Al-Maidah terdapat pelarangan menjadikan non-muslim sebagai auliya' dan pelarangan ini dungkapkan dengan beberapa pengukuhan, antara lain 1) pada larangan tegas menyatakan, janganlah kamu menjadikan orang-orang Yahudi dan Nasrani sebagai pemimpin-pemimpin. 2) penegasan bahwa sebagian mereka adalah pemimpin bagi sebagian yang lain. 3) ancaman bagi yang mengangkat mereka sebagai pemimpin, bahwa ia termasuk golongan orang-orang yang zalim. Akan tetapi, M. Quraish Shihab menyatakan bahwa larangan tersebut tidak bersifat mutlak. Ia mengutip salah satu penjelasan tokoh mufasir, Sayyid Thantawi yang membagi non-muslim menjadi tiga kelompok.

Pertama, adalah mereka yang tinggal bersama kaum muslimin dan hidup damai bersama kaum muslimin. Kelompok ini memiliki hak dan kewajiban sosial yang sama dengan kaum muslimin. Tidak ada larangan untuk bersahabat dan berbuat baik kepada mereka. Sebagaimana firman Allah:

"Allah tidak melarang kamu untuk berbuat baik/ memberikan sebagian dari harta kamu dan berlaku adil terhadap orang-orang yang tiada memerangimu karena agama dan tidak (pula) mengusir kamu dari negerimu. Sesungguhnya Allah menyukai orang-orang yang berlaku adil." (Q.S. AlMumtahanah [60]: 8).

Kedua, kelompok yang memerangi dan merugikan kaum muslimin. Kaum muslimin dilarang menjalin hubungan harmonis dengan mereka. Salah satu ayat Al-Qur'an menyinggung perihal kelompok ini yang berbunyi:

"Sesungguhnya Allah hanya melarang kamu menjadikan sebagai teman-teman dekat kamu orang-orang yang memerangi kamu karena agama dan mengusir kamu dari negerimu dan membantu (orang lain) untuk mengusirmu". (QS. Al-Mumtahanah [60]: 9)

Ketiga, kelompok yang tidak secara terang-terangan memusuhi kaum muslimin, tetapi terdapat indikator yang menunjukan bahwa mereka lebih bersimpati kepada musuh-musuh Islam ketimbang kaum muslimin. Terhadap kelompok ini, Allah memerintahkan kaum beriman untuk selalu berhati-hati.

Kemudian, pada idiom terakhir ayat ini: "Sesungguhnya Allah tidak memberi petunjuk kepada orang-orang yang zalim." Quraish Shihab menjelaskan bahwa yang dimaksudkan oleh idiom terakhir dala ayat ini bukanlah tidak menyampaikan tuntunan agama kepada mereka, melainkan mereka tidak diantar menuju ke jalan kebahagiaan.

\section{Perbandingan Dua Tafsir}

Hamka dan M. Quraish Shihab dalam menuliskan kitab tafsirnya, sama menggunakan metode tahlili (analitis), yaitu menafsirkan ayat-ayat Al-Qur'an dengan memaparkan berbagai aspek yang terkandung di dalam ayat-ayat yang sedang ditafsirkan itu serta menerangkan makna-makna yang tercakup di dalamnya sesuai dengan keahlian dan 
kecenderungan dari mufassir yang menafsirkan ayat-ayat tersebut. ${ }^{46}$ Selain itu, dua kitab tafsir ini memiliki kesamaan corak penafsiran adabi ijtima'i, sebuah corak yang menggambarkan serta menguraikan penafsirannya berbasis sosial kemasyarakatan.

Dalam sistematika kepenulisan kitab Tafsir Al-Azhar, Hamka lebih menjelaskan makna yang terkandung dalam kalimat dengan utuh. Seringkali Hamka mengaitkan pengalaman pribadinya dalam proses penafsiran suatu ayat. Ia juga menyajikan beberapa data historis sebagai argumentasi penguat bagi penafsirnnya, di samping menggunakan kaidah hukum. Berbeda dengan M. Quraish Shihab, dalam proses penafsiran, ia selalu membahas tiap pokok kata yang memiliki makna yang perlu untuk dijelaskan secara detail pengembangan maknanya. Ia juga sering mencantumkan asbab nuzul (jika ada) dan mengutip beberapa pendapat mufassir lain, seperti al-Biqa'i, Thaba'thaba'i dan lainnya.

Selanjutnya, beralih pada penafsiran ayat 51 surat Al-Maidah. Baik dalam Tafsir Al-Azhar atau Tafsir Al-Misbah, kedua mufassir sama-sama menyatakan bahwa ayat ini berisikan sebuah larangan. Hamka mengungkapkan bahwa larangan ini bersifat mutlak, sedangkan M. Quraish Shihab tidak menyamaratakan seluruh non-muslim pasti melakukan hal buruk kepada muslim, sehingga larangan tersebut tidak bersifat mutlak. Selain itu, kata auliya' tidak hanya diterjemahkan dengan pemimpin-pemimpin, mengingat kata auliya' merupakan sebuah term yang multitafsir, maka M. Quraish Shihab lebih memilih menguraikan makna dan pengembangannya dari kata tersebut.

Ada hal menarik dalam penjelasan Hamka mengenai larangan dalam ayat ini. Dalam penafsirannya, Hamka memberikan sebuah pengecualian yang berbeda dengan M. Quraish Shihab, yaitu kebolehan memberikan kepercayaan kepada non-muslim untuk menduduki suatu jabatan, dengan catatan pimpinan tertinggi tetap dipegang oleh muslim dan tidak dikhawatirkan terjadi sutau pembelotan. Hamka menyatakan:

"Di dalam pemerintahan Islam, Penguasa Islam dibolehkan memberikan kepercayaan kepada pemeluk agama lain itu memegang satu jabatan, sebab pimpinan tertinggi adalah di tangan Islam. Sebab itu tidaklah ada kekhawatiran. Tetapi kalau timbul kuatir tidaklah boleh."

Dari perbedaan penafsiran di atas, penulis menemukan bahwa sebuah hak untuk menjadi pemimpin bagi kalangan non-muslim masih sangat terbatas, karena kebolehan tersebut berada pada sebuah pengecualian. Seharusnya dalam konteks negara demokrasi, terdapat sebuah model penafsiran yang tidak hanya terpaku pada teks saja, melainkan juga mempertimbangkan kelompok-kelompok yang terpinggirkan, sehingga dapat memberikan manfaat secara luas tanpa adanya unsur diskriminatif sedikitpun, seperti pembedaan antara mayoritas-minoritas.

\section{Faktor adanya perbedaan penafsiran}

Adanya perbedaan peafsiran antara Hamka dan M. Quraish Shihab yang tertuang dalam kedua karya mereka, menurut hemat penulis, disebabkan beberapa faktor yang

${ }^{46}$ Nashruddin Baidan, Metode Penafsiran Al-Qur'an, (Yogyakarta: Pustaka Pelajar, 2011), 68. 
melatarbelakanginya, yaitu Pertama, faktor pendidikan. Dalam pendidikan formal, Hamka hanya mengenyamnya hingga kelas tiga sekolah desa dan seumuran jagung dia nyantri di salah satu pesantren di daerahnya. Pendidikannya lebih banyak didominasi dengan membaca dan otodidak. Selain itu, ia juga banyak belajar tentang Islam ketika berada di Yogyakarta. Sedangkan M. Quraish Shihab, sejak dini, ia telah dididik dan arahan dari ayahnya. Karena di kalangan keluarganya, pendidikan adalah hal terpenting yang harus diperhatikan. Sehingga tidak heran, mulai dari strata satu hingga doktor, ia menekuni bidang yang sama di almamater yang sama juga.

Kedua, kondisi sosial politik. Kendati embrio Tafsir Al-Azhar sudah ada sejak pengajian subuh di masjid Al-Azhar Jakarta, tidak dapat dipungkiri bahwa penulisan Tafsir Al-Azhar dapat diselesaikan oleh Hamka ketika ia dipenjara oleh Pemerintahan Soekarno. Selain itu, Hamka menjalani kehidupannya tidak hanya pada satu masa saja, ia hidup sejak masa penjajahan Belanda hingga Orde lama. Sehingga wajar, jikalau dalam penafsirannya terkadang dikaitkan dengan kondisi sosial yang ia jalani di masa itu. Adapun M. Quraish Shihab mulai menulis Tafsir Al-Misbah pada tanggal 18 Juni 1999. Ketika itu, ia menjabat sebagai Duta Besar Indonesia untuk Mesir di masa pemerintahan B.J. Habibie. ${ }^{47}$ Proses penulisan kitab tafsir tersebut menghabiskan waktu sekitar lima tahun. M. Quraish Shihab menyelesaikan penulisan tersebut pada 5 September 2003. Sehingga bisa dikatakan Tafsir Al-Misbah ditulis setelah masa pemerintaha Orde Baru. Oleh sebab itu, tidak mengherankan apabila penafsiran Hamka dalam Tafsir Al-Azhar disajikan dengan sedikit keras dibanding Tafsir Al-Misbah yang sangat halus dalam penyajian dan penafsirannya.

\section{Penutup}

Hamka menafsirkan surat Al-Maidah ayat 51 sebagai larangan mutlak untuk menjadikan non-muslim sebagai pemimpin di kalangan muslim. Ia berargumen bahwa non-muslim akan selalu berusaha berbuat buruk kepada muslim. Sedangkan M. Quraish Shihab menafsirkan ayat ini tidak sebagai larangan mutlak untuk menjadikan non-muslim sebagai auliya'. Ia masih membagi non-muslim menjadi tiga bagian. Menurutnya, seorang non-muslim yang hidup damai dengan muslim memiliki hak dan kewajiban yang sama dengan muslim, sehingga begitu juga dalam hak untuk menjadi pemimpin.

Penafsiran berbeda yang disajikan oleh dua tokoh berbeda ini, hemat penulis disebabkan beberapa faktor, antara lain pertama, pendidikan, Hamka dikenal sebagai orang yang otodidak dan banyak belajar dari membaca. Sedangkan M. Quraish Shihab, mulai sejak kecil hingga doktor, pendidikan (formal) merupakan suatu hal penting yang harus diperhatikan. Kedua, kondisi sosial politik. Hamka menulis kitab Tafsir Al-Azhar pada saat ia dipenjara selama dua tahun oleh pemerintaha Soekarno. Sedangkan M. Quraish Shihab menulis kitab Tafsir Al-Misbah, ketika ia menjadi Duta Besar Indonenesia di Mesir pada masa pemerintahan B.J. Habibie. Sehingga tidak heran, apabila penyajian dan penafsiran Tafsir Al-Misbah lebih halus dibandingkan Tafsir Al-Azhar.

${ }^{47}$ M. Quraish Shihab, Tafsir Al-Misbah; Pesan, Kesan dan Keserasian Al-Qur'an, Jilid 15 (Jakarta: Lentera Hati, 2006), 645. 
Dalam Tafsir Al-Misbah, kendati terdapat sebuah kebolehan menjadikan non-muslim yang dapat hidup damai dengan muslim sebagai auliya'. Hemat penulis, hal ini masih menggambarkan adanya sekat antara kelompok mayoritas (muslim) dan minoritas (nonmuslim) dengan peletakan kebolehan tersebut dalam pengecualian. Padahal dalam negara demokrasi, semua masyarakat memiliki hak dan kewajiban yang sama tanpa adanya pembedaan yang didasari perbedaan keyakinan dan sebagainya. oleh sebab itu, hemat penulis, diperlukan sebuah penafsiran yang tidak hanya fokus pada teks saja, melainkan juga mempertimbangkan kondisi sosial masa kini serta kelompok-kelompok yang seringkali terpinggrikan, sehingga dapat memberikan manfaat secara luas.

\section{Daftar Pustaka}

Ahnaf , Mohammad Iqbal. 2016. "Aksi Bela Islam", Akankah Mengubah Lanskap Muslim Indonesia? dalam Jurnal Ma'arif.

Ambarity, Hasan Muarif. 2004. Supelemen Ensiklopedi Islam. Jakarta: Ichtar Baru Von Hoeve.

Baidan, Nashruddin. 2011. Metode Penafsiran Al-Qur'an. Yogyakarta: Pustaka Pelajar.

Burhani , Ahmad Najib. 2016. Aksi Bela Islam: Konservatisme dan Fragmentasi Otoritas Keagamaan dalam Jurnal Ma'arif.

Dzuhayatin, Siti Ruhaini. 2015. Islam, Kepemimpinan Non-Muslim dan Hak Asasi Manusia, dalam Fikih Kebinekaan. Ma'arif Institute dan Mizan : Bandung.

Hamka. 1982. Ayahku : Riwayat Hidup Dr. H. Abdul Karim Amrullah dan Perjuangan Kaum Agama di Sumatera. Jakarta: Yayasan Uminda.

Hamka. 2007. Tafsir Al-Azhar. Singapura: Kerjaya Print.

IRCR, 2015. Islam dan Urusan Kemanusiaan, Konflik, Perdamaian dan Filantropi. Jakarta: Serambi.

Muhammad, Hery, dkk. 2006. Tokoh-tokoh Islam yang berpengaruh Abad 20. Jakarta: Gema Insani Press.

Nadziroh, Lulu. 2017 Skripsi Pemimpin non-Muslim menurut Ibnu Taimiyah dan Relevansinya dengan Kontroversi Pilkada di DKI Jakarta Tahun 2017. UIN Sunan Kalijaga: Fakultas Ushuluddin dan Pemikiran Islam.

Shihab, M. Quraish. 2002. Tafsir Al-Misbah. Jakarta: Lentera Hati.

Shihab, M. Quraish. 2007. Secercah Cahaya Ilahi. Jakarta: Lentera Hati. 
Shihab, M. Quraish. 2014. Lentera Al-Qur'an: Kisah dan Hikmah Kehidupan. Bandung: PT Mizan Pustaka.

Shihab, M. Quraish. Membumikan Al-Qur'an, Fungsi dan Peran Wahyu dalam Kehidupan Masyarakat. Bandung : PT Mizan Pustaka.

Shobahussurur. 2008. Mengenang 100 Tahun Haji Abdul Malik Karim Amrullah, Hamka. Jakarta: Yayasan Pesantren Islam al-Azhar.

Suprapto, M. Bibit. Ensiklopedia Ulama Nusantara. Jakarta: Gelagar Media Indonesia.

Supyan, Muhammad Dian. 2013. Skripsi Kepemimpinan Islam dalam Tafsir Al-Misbah Karya M. Quraish Shihab. UIN Sunan Kalijaga: Fakultas Dakwah.

Susanto, Ahmad. 2009. Pemikiran Pendidikan Islam. Jakarta: Amzah.

Syahrul, Achmad. 2009. Skripsi Penafsiran Hamka tentang Syura dalam Tafsir al-Azhar. UIN Sunan Kalijaga: Fakultas Ushuluddin dan Pemikiran Islam.

Tamara, Nasir, dkk. 1996. Hamka di Mata Hati Umat. Jakarta: Pustaka Sinar Harapan.

Wahid, Wawan Gunawan Abdul. 2015. Fikih Kepemimpinan Non-Muslim dalam Fikih Kebinekaan. Ma'arif Institute dan Mizan : Bandung.

Yusuf, Yunan. 1990. Corak Pemikiran Kalam Tafsir Al-Azhar. Jakarta: Pustaka Panjimas. 